\title{
COMMUNITY PARTICIPATION IN WETLAND CONSERVATION IN NEPAL
}

Utsala Shrestha MSc (Ag) ${ }^{1}$

\begin{abstract}
Community participation plays vital role in the development of capacity for the management and utilization of their resources in sustainable way. There are ample success stories for proper management of common property resources through community management. Wetland resources are widely used by the local communities for their sustenance and economic well-being. In such case, local participation is effective tool for establishing an ecologically balanced use of available land and water resources. The participation of the wetland users is crucial for extenuating the problems related to wetland. This paper includes some ideas about community participation and role of local people in wetland conservation and management, reason for conservation of wetland sites, wetland policy based on local participation, and approaches for ensuring participation in wetland conservation programs.
\end{abstract}

Key words: Community participation, wetland conservation, and wetland policy

\section{INTRODUCTION}

Wetlands of Nepal have economic, ecological, aesthetic, socio-cultural and religious values. They provide habitats for several species of wildlife and lie within various ecosystems of high-mountains and lowland plains. These wetlands are important ecosystems and utilized for the benefits of humankind. Rice cultivation, fishing and collection of wetland products are basic activities performed by local people. Likewise rendering ferry service, cattail technology, craft manufacturing and weaving are other such income generating activities of wetland dependent people. However, adverse effects remark in many cases: many rural communities have poor knowledge on sustainable utilization and more often conflicts arise for the use of wetland resources.

Wetlands are crucial for their rich biodiversity (32 species of mammals, 461 species of birds, 9 species of turtle, 20 species of snake and 28 species of fish- in Terai) and also for maintaining various sources of underground water, preventing lands slides and controlling the loss of nutrients. Religiously, lakes and rivers are important for many festivals such as the Chhat festival in the eastern and central Terai. Furthermore, people living near Koshi river system (Barahachetra), Narayani river system (Devghat) and Karnali River consider the Gangetic Dolphin as a deity and as reincarnation of god (IUCN, 2004). Since the sustainable utilization and the conservation of wetland resources depend on the degree of involvement of local communities, it is important to prioritize programs of bringing user groups together for conservation. Most of the wetlands of Nepal are under threatened conditions, as they have been exploiting the resources indiscriminately without considering its impact.

The possible way of utilising the wetlands in a sustainable way has become an extreme necessity to promote the community's welfare in terms of the resource use. In some areas, local communities have already begun to replicate the conservation development program without any external help (Rijal, 2001). Importance of community role in wetland conservation programs should rely on understanding of livelihood resources and management of resources through their own skill and knowledge. Nevertheless, the conservation of wetland requires public support, appropriate government legislation, and conservation programs.

1 Horticulture Development Officer, FDO, Kirtipur. Email: utsala@hotmail.com 


\section{OBJECTIVES}

The overall objective of this review paper is to develop the idea about community participation and their efforts in the conservation of wetlands in Nepal. Especially the specific objectives are as follows:

- To develop concept about community participation,

- To know importance of community role in wetland conservation and

- To acknowledge how the local community can be participated in conservation programs.

\section{WETLAND CONSERVATION}

Wetland resources are global asset of enormous value to present and future generations, since they are vital to humanity's economic and social development. Wetland conservation incorporates practical embracing preservation, maintenance, sustainable utilization, restoration, and enhancement of the natural environment. It takes into considerations of understanding its increasing importance, necessity, and wise use of wetland resources through active and expert conservation planning.

Massive deforestation, unplanned urbanization and industrialization, public ignorance of wetland values, functions and fragility, and inadequate or conflicting management structures are the main causes of wetland degradation (Pradhan and Shrestha, 1994). Social and behavioral factors of local community have led to destruction of wetlands. The major causes of decline and loss of wetland resources are due to loss, fragmentation, and modification of habitat, unsustainable use of water resources, siltation, over exploitation unplanned development and haphazard implementation of development activities, unregulated garbage and sewage disposal, eutrophication, introduction of exotic fish farming, and use of persistent organic pesticides (Joshi et al., 2003). Thus, wetland values and functions affected in most cases as there is over exploitation, uncontrolled access for non-community members and outsiders using resources without caring for the regeneration capacity. Few examples related to impacts of degradation are:

- The Bagmati River in Kathmandu valley's urban area or close to it no longer have any fresh water aquatic life and the river is almost dead (ICIMOD, 2006; ICIMOD, 2007). Excessive quantities of non-biodegradable debris (plastic materials) are becoming a serious hazard to fish and it degrades the water quality.

- The lake Rupa has achieved hyper-eutrophic condition due to heavy siltation from the catchments areas and organic load from decaying aquatic weeds from the lakes. It has promoted negative impact in the lakes. Over 12600 cattle ecorded grazing the shoreline forests at Ghodaghodi, where the composition of wetland vegetation is gradually changing into terrestrial communities because of over-grazing (IUCN, 2004).

- GoV/N established Fisheries Research Centre (FRC) at Phewa Lake failed as to there was conflict between centre and local fishermen in the use of resources, which led to depletion of resources. Local fishermen considered the centre a threat to their livelihood (Bhandari, 1995).

Sustainable wetland management has received most thought within the role of community participation and the value of wetlands sustain only if managed and utilized with sound knowledge and cooperation between/among communities. The Ramsar Convention has also stated that the wise use of wetlands is their sustainable utilization for the benefit of mankind in a way compatible with the maintenance of the natural properties of the ecosystem. 


\section{ROLE OF COMMUNITY IN WETLAND CONSERVATION}

Importance of cultural heritage, indigenous knowledge and local practices appreciated in the wise use of wetland resources and local people's role in the stewardship of wetland area in Penang Statement of AWS (2001). However, local community dependence on wetland resources with low involvement in their management, weak, un-diversified, and insecure livelihoods based on the direct exploitation of natural resources causes hindrance in conservation.

Wetlands provide free goods and services to numerous rural and urban communities hence maintenance of the essentials values and function of wetlands is the major role of community. Maintenance: with the preservation of the hydrological and ecological processes, is the vantage to maintain the essential values and function of wetlands in Nepal. The conservation methods are in progress and the major issues and conservation methods in wetland sites depicted in Table 1.

Table 1: Issues and conservation practices adopted in different wetland sites of Nepal

\begin{tabular}{|c|c|c|c|}
\hline $\begin{array}{l}\text { Wetland } \\
\text { sites }\end{array}$ & Issues & Conservation methods & Advantages \\
\hline $\begin{array}{l}\text { Beesh } \\
\text { hazar lake }\end{array}$ & $\begin{array}{l}\text { Felling of trees } \\
\text { Overgrazing } \\
\text { Drainage } \\
\text { Fill-in } \\
\text { Vegetation succession }\end{array}$ & $\begin{array}{l}\text { Local are keen to conserve and } \\
\text { protect the resources from } \\
\text { uncontrolled human } \\
\text { encroachment and intervention }\end{array}$ & $\begin{array}{l}\text { Ecotourism , } \\
\text { recreational activities } \\
\text { can encourage the } \\
\text { people participation }\end{array}$ \\
\hline $\begin{array}{l}\text { Ghodagodi } \\
\text { lake }\end{array}$ & $\begin{array}{l}\text { Felling of trees } \\
\text { Overgrazing } \\
\text { Drainage } \\
\text { Siltation } \\
\text { Construction }\end{array}$ & $\begin{array}{l}\text { Build cattle sheds an } d \\
\text { cottages near the temple }\end{array}$ & $\begin{array}{l}\text { Fishing harvesting lotus, } \\
\text { collection of fodder } \\
\text { Recreation, watering } \\
\text { domestic animals }\end{array}$ \\
\hline $\begin{array}{l}\text { Karnali } \\
\text { floodpain }\end{array}$ & $\begin{array}{l}\text { Human encroachment } \\
\text { deforestation }\end{array}$ & & $\begin{array}{l}\text { Drift wood collection, } \\
\text { fishing panning(extract } \\
\text { gold from motes found } \\
\text { on the bank of river ) }\end{array}$ \\
\hline $\begin{array}{l}\text { Halkhoria } \\
\text { daha }\end{array}$ & $\begin{array}{l}\text { Low water level } \\
\text { Vegetation succession } \\
\text { Grazing and watering } \\
\text { Siltation } \\
\text { Pumping out of water }\end{array}$ & $\begin{array}{l}\text { Stop practice of contract } \\
\text { fishing, banning introduction of } \\
\text { exogenous fish. }\end{array}$ & $\begin{array}{l}\text { Pumping out water, } \\
\text { sedimentation }\end{array}$ \\
\hline Lumbini & $\begin{array}{l}\text { Water retention } \\
\text { Lack of planting }\end{array}$ & $\begin{array}{l}\text { Local willing to cooperate with } \\
\text { the trust in establishing an } \\
\text { area with natural vegetation } \\
\text { enriched with biodiversity } \\
\text { Interest in planting trees }\end{array}$ & $\begin{array}{l}\text { Blue bulls depredate } \\
\text { their crop field and } \\
\text { destroy the grains and } \\
\text { crops }\end{array}$ \\
\hline
\end{tabular}

Source: IUCN, Nepal

Community can play pioneering role in many functions that are necessary for sustainability and equitability; merely the conservation programs should represent local communities for the consultation in plan development phase. Moreover, local communities are important stakeholders in using resources. Wetlands have many stakeholders at community level with diverse interests, the major ethnic groups dependent on wetlands in the kingdom are small fractions of the population and are scattered over regions and these are the major wetland users. Many of them have their own language, culture, physical features and way of life they may live along the river basins and wetland sites. People depended on wetlands 
resources own very little and they are shy and provincial in nature. They have remained unchanged in their traditional culture despite the changes taking place around them (Bhandari, 1998a). Wetland depended people can play major role in the conservation practices. The people which mainly involved in wetland activities are Sunuha (Karnali), Mallah (Gandak), Kewat (Nawalparsi), Bote and Mushahar (Nawalparasi, Chitwan), Pode (Phewa lake), Gongi (Koshi), Darai and Kumal, (Chitwan), Dasuhad (Parsa) Sahani (Parsa and Bara) Bantar (Sunsari and Saptari), Mukhia (Rautahat), Danuwars (Chitwan ,Siraha, and Sinduli), Barhamus (Gorkha), Majhis, Tharus and Kushar (Terai). Since local people are pioneer for the conservation of wetlands, they should let in for participation in conservation for following reasons:

- Local people provide information required for making wetland inventory, necessary data and socioeconomic condition of resources.

- They can utilize their knowledge, skill to produce wetlands products and take benefits from them.

- They can disseminate the information regarding threats and dangers to different organization.

- They help in maintaining ecological balances by wise utilization of wetland resources.

- Active participation of local people in plan development process is essential for efficient planning phase.

- They are more attached to wetlands hence should provide any conservation issues to handle them.

Thus, community is an important stakeholder in using resources. Any activities that exert negative impact on wetlands should be discouraged or restricted. The major roles they can further elaborate are:

- They should prohibit the dumping of chemical pollutants, domestic garbage, industrial waste, toxic substances, and the use of electric current and explosives in the wetland sites.

- They must not allowed any project to take over community land or any unwanted service they are not willing to do or any illegal use of resources such as wetland drainage.

- They must have the sense of distinguishing problem and prioritizing the conservation activities.

- They should not overexploit the wetlands and work under safe standards set for regeneration capacity of wetland resources.

- They must cooperate in environment management program that secures their right and gains.

- Rural communities must cooperate with project to prioritize the problem that seeks the immediate solution.

\section{WETLAND CONSERVATION AND LOCAL COMMUNITY PARTICIPATION}

Wetland conservation is a long termed endeavor that has often allowed local communities to increase their revenue or meet their needs in the short term. Conservation must includes educational activities and provide local communities with new sources of income or alternatives allowing them at least maintain and if possible improve their living standards. Many examples of program failure have cited in rural areas due to lack of local participation. People should be target of any conservation activities and involved in all phases of wetland conservation and management. An approach excluding consultation with local communities takes no account of the role and knowledge of people who have manages 
the areas to ensure their own livelihood. Recognizing the importance of wetland dependent people, National Wetland Policy (2003) has identified the local people participation as the one of the main element to conserve and manage wetland resources wisely and in a sustainable way. The Wetlands Management Policy that incorporates local participation is (HMG/MoFSC, 2003)

1. Conserve and manage wetlands with local people's participation for their benefit, while maintaining environmental integrity according to the terms and spirit of the Ramsar Treaty.

2. Translate into reality the concept of wise use of wetland resources by providing equal opportunities based on local people's participatory management of wetlands.

3. Make wetlands conservation and management activities effective by involving local residents, communities and community-based organizations.

4. Conduct social and economic development activities that are advantageous to local residents and conserve natural resources for the benefit of present and future generations.

5. Conserve endangered and common wildlife species, aquatic fauna and other genetic sources dependant on wetlands.

6. Develop environmental friendly tourism with minimum environmental impacts and mobilize acquired profits, as far as practicable, for wetlands management and the benefit of local people.

7. Ensure local people $s$ participation in the preparation of work plans for the conservation and management of wetlands.

8. Preserve the experience, practice, skill and knowledge of the ethnic groups who are dependent on wetlands, and promote wetlands conservation and management based on their experience.

9. Identify the problems and issues pertaining to wetlands management and implement the management action plan prepared with local people s participation to address the issues at the local level.

10. Formulate wetlands management plan and make necessary legal and administrative arrangements for the representation of local people and organizations in the management committee.

Although, in conservation approach, we seek to cooperate with local communities, the full participation of women is less. Women who often play a major role on resources use, their status generally does not allow them to benefit from the necessary legal and financial means, nor participate fully in household and community decision making. It is therefore necessary, if the participation of women is to become a reality, to plan actions that address them specifically.

\section{COMMUNITY PARTICIPATION IN PROJECT AND PROGRAMS}

People seem quite receptive to external assistance, and it would be helpful if the respective roles and responsibilities are discussed delineated at the outset. External agencies should start a confidence building program to win the people's trust, support and participation and involvement, marginalization would prevent productive advancements in wetland conservation (Bhandari, 1998b). Any project should convince the community to participate in the programs before its implementation to achieve the objectives of affective and efficient protection and management of wetland resources. Local users are the sole owner as well as the protector of their resources. Wetland conservation program if do not generate local income; users will not participate in such approach (Pradhan and Shrestha, 1994). 


\section{STEPS TO INVOLVE LOCAL PEOPLE IN PARTICIPATION}

1. Group formation of the community users (real protectors and managers of wetland resources) through systemic identification

2. Creation of awareness regarding function, benefits and uses of wetland resources and the need to conserve them for the community

3. Identification of local people's knowledge, skill and practice regarding wetlands

4. Assessment of felt needs of group through participatory learning exercises

5. Implementation of plan and its management

6. Promotion of their innovations and traditional research for the sustainable use of wetlands resources

7. Promotion of women's participation for the conservation, management and wise use of wetlands

8. Gradual implementation of international treaties for wetlands conservation

9. Dissemination of information to raise public awareness about wetlands

The people participation in real sense in the main stream of conservation is the most important building block of community participation. If the wetlands are resource poor and there is no alternative resource available, there will be great difficulty in community participation in conservation. Local participation in conservation can be motivated through

- Development of eco-tourism to allow income generating activities

- Creation of a buffer zone

- Skill training to local people for self-employment

- Upgrading mat weaving and fan making technology

- Establishment of paper factory for local employment

- Judicial sanctions to people when committed crime

- Establishment of health and veterinary posts

- Seeking other alternatives to reduce cost and conflict

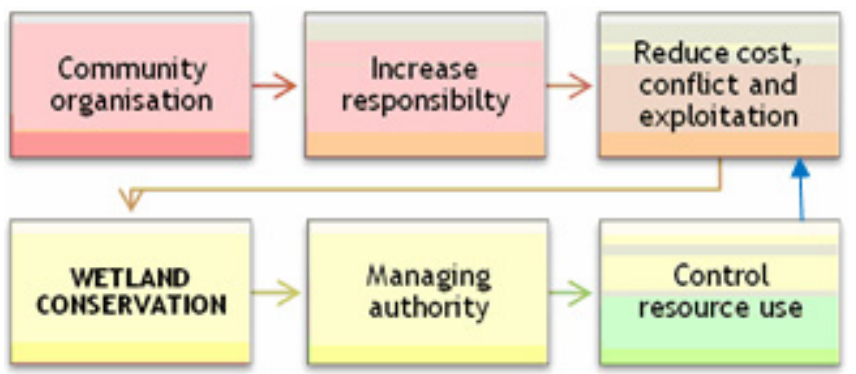

Fig.1: Interrelationship between managing authority and community participation

Therefore, to reduce the dependency of the people on reserve resources building of alternative strategies to supply their need from outside resources and technologies is must. These alternative strategies for conservation explored from local environment might be the best solution.

\section{SUGGESTIONS}

1. The efficacy of the conservation of wetlands is only through the exchange of knowledge, skills and expertise concerning wise use, conservation, management and restoration of wetlands and their biodiversity. 
2. The co-management between local and indigenous community supported by partnership programs is crucial to promote cultural heritage, local practices in sustaining wetlands, maintain biodiversity and avoiding adverse impacts on wetlands.

3. Communication, education, public awareness program of the Ramsar convention should be adopted along with review of traditional technique of sustainable wetland use adopted by communities.

4. The special role of women in the wise use of wetlands be acknowledged and all wetland policies in the region place a high priority on their effective participation.

5. Integrating conservation and development: conservation actions should be undertaken to protect the natural properties of the wetland ecosystem. The value of wetland for mankind depends upon maintenance of these properties. Conservation measures may require the prohibition or restriction of some of the activities carried out by local communities-including communities, which depend on the wetland for part of the year only.

6. Policies should be formulated in such a way that the gradual phase-out of the community's use of the wetland site be implemented in order to carry on the value and prospects of the Conservation of the Wetland of International importance.

7. It is also suggested that local participation in conservation can be motivated through

- Development of eco-tourism to allow income generating activities

- Creation of a buffer zone

- Skill training to local people for self-employment

- Upgrading mat weaving and fan making technology

- Establishment of paper factory for local employment

- Judicial sanctions to people when committed crime

- Establishment of health and veterinary posts

- Seeking other alternatives to reduce cost and conflict

\section{CONCLUSIONS}

Maintaining environmental quality and food security is the major challenge of the twentyfirst century, which relate directly to wetland. Participatory integrated wetland management has become the accepted approach to managing wetlands. Community role in the conservation activities is quite appreciating if they go hand in hand for sustainable utilization of wetland resources and seeks for the alternatives to reduce the pressure on wetland. Through different activities and policy based on local participation, we can be optimistic that once the people made aware, educated and trained, they will be able to understand the importance, threats and possible solutions for conservation and management of wetlands. Hence, it is imperative to educate the local communities about the value of wetlands (especially for the threatened Ramsar sites) and its wise use.

The local communities in wetland areas must be motivated and mobilized to work together, utilize their indigenous knowledge so that they can improve the wetland ecology and uplift their living styles. Moreover, it is important to secure community participation mainly the wetland users and stakeholders in sustainable management of wetland resources. For the successful wetland conservation and management, the community should be able to give and receive information about the wetlands, valuation and existing biodiversity. The interaction among ethnic people relying on wetlands and community development workers enhances efficiency in the management resources. Community participation in this regard promotes self-awareness, self-confidence, and self- reliance at all levels of the community structure. 


\section{REFERENCES}

AWS, 2001. The Penang statement on regional cooperation through paternership for wise use of wetlands, Asian wetland symposium, 27-30 August, 2001, Ramsar Center, Japan..

Bhandari, B., 1995. Wetland bio-diversity in Nepal: a case study of Koshi Tappu Wildlife Reserve. In: Proceeding of the editorial meeting of Asian Bio-diversity and Wetland, Awareness of biodiversity in wetland in Asia, 24-26 February, 1994, Serpong-Tangerang, Indonesia, Ramsar Centre Japan, pp.50- 61.

Bhandari, B., 1998a. An inventory of Nepal's terai wetlands. IUCN- The World Conservation Union, Kathmandu, Nepal.

Bhandari, B., 1998b. Community participation in conservation projects in Nepal: issue papers on Nepal's wetland. Wetlands and Heritage Unit, IUCN, Kathmandu, Nepal.

MoFSC, 2003. National wetland policy 2003 (2059). Ministry of Forestry and Soil Conservation, Nepal.

ICIMOD, 2006. Watershed approach to securing resilient livelihoods and ecosystem services. In: Sustainable Mountain Development in the Himalayan region: Managing Watersheds in the Himalayan Region. International Centre for Integrated Mountain Development, No 51 winter 2006, pp.22-24.

ICIMOD, 2007. Drinking water resources. In: G. Rana, A. B. Murray, D. R. Maharjan and A.K. Thaku (eds.), Kathmandu Valley Outlook, pp. 57-71. ICIMOD, Kathmandu.

IUCN, 2004. A review of the status and threats to wetlands in Nepal: IUCN wetland and water resources programme. IUCN, the World Conservation Union.

Joshi, A. R., S. L. Shrestha and K. Joshi (eds), 2003. Enviroment Management and Sustainable Development at the Crossroad, pp.92-103. AnKus, Kathmandu, Nepal..

Pradhan, G. B. and B. C., Shrestha, 1994. Awareness and community involvement in wetlands management. In: B. Bhandari, T. B. Shrestha and J. McEachern (eds.), Safeguarding wetlands in Nepal, Proceedings of the national workshop on wetlands management in Nepal. IUCN, Kathmandu, Nepal.

Rijal, A., 2001. Nepal eco-region based conservation. WWF. Baluwatar, Kathmandu. 